\title{
Stoicism, a Philosophical Basis for Ecology?
}

\author{
Koffi Alladakan \\ University of Abomey-Calavi, Cotonou, Benin \\ Email: koffalla@yahoo.fr
}

How to cite this paper: Alladakan, K. (2021) Stoicism, a Philosophical Basis for Ecology? Open Access Library Journal, 8: e7237

https://doi.org/10.4236/oalib.1107237

Received: February 10, 2021

Accepted: April 26, 2021

Published: April 29, 2021

Copyright (c) 2021 by author(s) and Open Access Library Inc.

This work is licensed under the Creative Commons Attribution International License (CC BY 4.0).

http://creativecommons.org/licenses/by/4.0/

(c) (i) Open Access

\begin{abstract}
Through its ideal of "living in harmony with nature", the Portico appears to be a philosophy that invites men to take the relationship with the world seriously. In order to achieve wisdom, the essential mark of which is sobriety, it has established principles, some of which seems to have an ecological value. While considering nature as an organic and spiritual entity which parts together form a whole, stoicism posits that it constitutes the destiny whose laws are inescapable and instructs men never to rebel against the already established order but always to seek the best way to collaborate with it so as not to suffer the evils of their action. With the principle of "universal sympathy", he adds that everything is interwined and interdependent so that one cannot touch other elements of the cosmos without acting on the whole. Through the principle of oikeiôsis, i.e. the appropriation of oneself, a familiarity with what is close, extending from the human species to other natural beings, to the whole earth, develops. Apart from all these doctrinal considerations, we discover paradoxically that Seneca's work conceals several clues relating to the environmental problems. In this sense, it would be difficult to deny that the philosophy of the Portico has nothing to do with the foundation of ecology. Rather, its interest would lie, in terms of effectiveness, in the education of virtue, consisting of a habitus animi, a disposition of the soul in a certain way, which naturally implies ecological behaviour.
\end{abstract}

\section{Subject Areas}

Philosophy

\section{Keywords}

Stoicism, Universal Sympathy, Oikeiôsis, Virtue, Ecology

\section{Introduction}

In Greco-Roman antiquity, if the whole philosophical tradition has given, in 
general, an importance to nature, it is stoicism which has considered, particularly, nature as a living organism. According to this doctrine, nature cannot be the result of chance, because its observation shows that there is a universal order which is the result of divine, providential and rational actions, whose knowledge is a determining factor for good behaviour. This follows from the Stoic ideal: "to live in harmony with nature" whose application could naturally imply a relationship of harmony and balance between men and nature and have a positive impact on the latter in terms of reducing the exploitation of resources, brief in terms of protection and protection of nature. In this sense, one might ask whether there is a link between Stoics and ecologists. Clearly, would the latter not have been inspired by Stoic philosophy to elaborate their thought that is ecology? In a clear way, would they not have taken inspiration from the Stoic philosophy to elaborate their thought that is environmentalism? In other words, would stoicism not be the distant source from which the idea of the need to maintain a harmonious relationship between man and nature arose? In other words, can we argue that the Stoics were the precursors of the ecologists? The objective of this research is to show that Stoicism would be the philosophy that would have served as the basis of ecology.

The study we have undertaken will first attempt to establish a relationship between Stoicism and Ecologism. The two doctrines seem to have almost the same language as regards the relationship that man must maintain with nature. Then we will present Stoic principles that have ecological value. It is the unity and order of nature that must be respected, the universal sympathy that expresses the link between the elements of nature and the familiarity that man develops towards it. Finally, we will highlight the evidences of Stoic thought concerning the environmental problems. Above all, it will be a question of showing that a virtuous life has a positive impact on nature.

\section{Link between Stoicism and Ecologism}

Despite the great gap that separates the Stoics and the ecologists in terms of time, it is curious to discover that they hold almost the same discourse on nature, inviting to maintain a relationship of harmony and balance between men and the cosmos.

The Stoic school, The Portico, was founded founded by Zeno of Kitium at the end of the 4th century B.C. in Athens, Greece. In Greek, this place was called the Stoa poikilè, which means painted Portico, from which comes the name Stoicism which is still called to the philosophy of the Portico. Over about six centuries, Stoicism has survived from Athens to Rome via Rhodes and its last representative is Marcus Aurelius who died in 180 AD. J.-C. The Stoic school based its philosophy on ancient naturalism, postulating that one must "live in harmony with nature", that is to say to know the laws of nature to live well. His teaching consists of three parts: physics, logic and ethics. Seneca was one of its great representatives in Rome during the imperial era, whose work came almost entirely 
to us and which deals essentially with the study of nature and ethics. But this one appears to have contributed the most to the influence and good reputation of the Portico. For ethics teaches men to live in harmony with himself, others and nature. And it seems that it is precisely at this level that one finds all the interest that one can have today for stoicism. More precisely the idea of environmentalism, the need to maintain a harmonious relationship between men and nature, would be an emanation of this philosophy; what is important to investigate.

Through its ideal of "living in harmony with nature", the Portico appears to be a philosophy that invites men to take their relationship with the world seriously. It demands harmony between men who must be in perfect harmony with nature. Nature has laws that mankind must observe in order to know happiness. Through this, the idea of ecology undoubtedly emerges. Because, to a certain extent, it is a question of men's relationship with nature. And when we draw a parallel between the Stoics' discourse on nature and that of the ecologists, we can affirm that Stoicism would constitute a philosophical foundation of ecology. If it is possible to arrive at one of the evidences of Stoic thought such as ecologism in the present case, which seems acceptable according to Duhot, he does not intend to say that the Stoics are the precursors of this ideology:

"The Stoic gaze considers continuity and systems, situates men in the totality of the universe and does not want to isolate anything from the whole.

Everything is interdependent and is inscribed in an ordered scale of beings. However, it would be quite naive to attribute this new convergence to an anticipatory vision of the Stoics and to consider them as precursors of any modern ideology. ...] The Stoics are precursors neither of systematic thought nor of ecology, any more than the atom of Democritus or Epicurus was of physicists. It is we who, by reconstructing our rationality, rehabilitate the possibility of conceiving things other than by reducing them to simple units [1]."

Neither the Epicureans nor the Stoics are respectively precursors of physicists and ecologists. The relevance and truthfulness of this statement is fully revealed in the sense that the Ancients and the moderns never lived together at the same time to think about the same problems. The difference between them is very large and although the term sometimes seems identical, it should be noted that their meanings differ. But as far as the case of the Stoics is concerned, it seems that it is possible to bring some nuance because what makes their thought specific and permanent, and thus their strength, is exactly their ethics, which makes them always seem to be ahead of their time; which even gives the impression of an anachronism about them. It is true that they have never directly posed the problem of the environment; for the preservation and safeguarding of the environment was not their main concern, and it only began recently in the 1970s. But since the ecological crisis is in fact an ethical problem, it is possible that Stoic thought has implicitly addressed it in its moral concerns in general. Thus, for example, Seneca (1993: 123, 3) thought of moral progress when he said that "it is 
indispensable to get used to living a short life"; this could make sense today on the ecological level. More precisely, an in-depth study has confirmed that the problem of the environment was not unknown to the Ancients, especially among the Romans, whose zeal for the organization and transformation of the world was no different from that which engendered the industrial revolution. To be convinced of this, we can refer to Fideli Paolo (2005, p. 7):

"[...] it is true that the concept of ecology has taken on primary importance in the modern world because of the dramatic consequences of the sometimes irrational use of industrial resources and the sometimes insufficient control of products harmful to man; however, this does not mean that-for other reasons and at another level-the question did not also arise for the Greeks and Romans, who lived in a world untouched by pollution [2]."

But the difference is that the scale of the environmental crisis in antiquity was absolutely less than that of the contemporary world. One could also add that if the problem had arisen, it was not the subject of any particular study; it was addressed through the moral and ethical concerns of the Ancients. On the basis of all this, it would be excluded that ecological thought was born ex nihilo without being inspired by ancient wisdom in general and stoicism in particular. Luc Ferry (2006, pp. 46-47) asserts this idea with this precision:

"However, if you want to compare this conception of [Stoic] morality to something you know and that still exists today in our societies, think of ecology. For ecologists, in fact, and in this they take up, although often without knowing it, themes from Greek Antiquity nature forms a harmonious whole that humans would be well advised to respect and even, in many cases, to imitate. It is in this sense that they speak, for example, not of the cosmos, but it comes down to the same thing, of 'biosphere' or 'ecosystems'. As the German philosopher who was a great theorist of contemporary ecology, Hans Jonas, said, 'the ends of man are domiciled in nature', which means: the objectives that human beings should ethically propose to themselves are inscribed, as the Stoics thought, in the very order of the world, so that the 'devoir-be'-that is, what one must do morally-is not cut off from being, from nature as it is [3]."

The connection between Stoicism and ecology seems to be quickly made, and it would not be at all exaggerated to see that most of the Stoic principles seem to express an ecological value, since their application naturally implies a relationship of harmony and balance between man and nature. It is the unity and order of nature that must be respected, the universal sympathy that expresses the link between the elements of nature and the familiarity that man develops towards it. In addition to all this, there is naturally the impact of the virtuous life which would be less on nature. In any case, it would be well possible to invite the reader to reread the Stoics, in this case Seneca, to be inspired by his ethics for a good management and protection of nature in general: 
"Seneca's ecological concerns boil down to the condemnation of the gluttony of the human species, which leads men to misuse natural phenomena. While it is quite clear that it is not a blind anachronism to speak of ecological concerns in an author who lived more than twenty centuries ago, it is important not to misunderstand the texts that condemn the philosopher's disrespect for nature and its goods. The ecological concerns in question are in reality only the result of the condemnation of moral depravity. Ecology, as protection of the environment, was of no more concern to him than the ruin of justice, friendship, benevolence and recognition, etc. Ecology represents only a rotten link in the long rotten chain of acts and representations of the human species [4] (P. Hounsounon-Tolin, 2011, pp.111-112).”

\section{Stoic Principles with Ecological Value}

Stoic principles of ecological value are concerned with the unity and order of nature that must be respected, the universal sympathy that expresses the link between the elements of nature and the familiarity that men develops towards it.

\subsection{Unity and Order of Nature}

We must begin by mentioning that the Portico is not a philosophy that can be reduced exclusively to ethics, wisdom or an art of living, but is above all a reflection on nature. And in this sense, it is undoubtedly the philosophy of Greco-Latin antiquity whose message most invites man to think about his relationship to the world. By developing the ancient ideal of "living in harmony with nature" as the supreme end of the search for happiness, he considered nature as a harmoniously ordered living organism. The Stoic cosmos, unlike that of the Epicureans, which is empty and subject to chance, is hierarchically constituted of beings of which man is at the top because he has the privilege of being rational in the same way as God, the creator, who governs the whole universe. It is characterized by unity, because we remember that Seneca $(1993,95,51)$ affirmed that "men constitute the members of a great body which is the world and which is one" [5]. The organization of nature, which is characterized by the order and regularity of the phenomena that take place in it, is the result of a perfect law that lies at its origin, and which is nothing other than the law of destiny, which is irreversible. It requires of all its subjects obedience and submission for the sake of a good cooperations which bring happiness, true freedom. Among all natural beings, man is the only one capable of understanding such an organization of the world, and it is precisely with the aim of participating in it voluntarily in order to preserve himself from the inconveniences that would result from his resistance. Since, his misfortune lies in his refusal to harmonize with the order of the cosmos, which is inescapable and can only be detrimental to him in case of disagreement. When he seeks to oppose or change the normal course of events instead of turning away from his ideas, he exposes himself to danger. They are at great risk because they cannot reverse or avoid the trend. One could, by inter- 
pretation and in a general way, situate the source of man's misfortunes, such as the environmental problem, in his rebellion that puts him at odds with the order of nature. This order being already established, the only possible solution is to adhere to it, not in the sense of resignation but rather of consent, of joyful acceptance. While obeying nature, man is not forbidden to take advantage of all the opportunities available to him to achieve what is possible. For example, according to an African proverb, "the waters of the river do not flow backwards", that is, naturally, "the water of the river does not return to its source"; just as it is not possible to block its way and oppose its passage; to do so is to go against the cosmic order. However, one can dredge a river in order to channel it, prevent its overflow and narrow its bed. One can also exploit its falls from the erection of dams to produce electrical energy. Most of the time, it is at the antipodes of the order of nature that men act out of ignorance and especially out of pleasure, which can lead to problems such as environmental problems. Seneca $(1993,122$, 8-9) witnessed this and wrote the following:

"Don't they come in the opposite direction of nature, these passionate amateurs of the winter rose, who by affusions of hot water, by skillful transplantations tear off a spring flower from the ground in the middle of the winter solstice? In the reverse of nature, those who plant an orchard at the top of the towers of their villa and who are on the roof and ridge of their home a forest that undulates in the wind and takes root at a height where it would hardly have raised the tops of its trees? Against nature those who throw the foundations of their thermal baths into the sea and do not believe they can swim voluptuously enough unless their warm water basins are beaten by the stream and the storm? Having made it a rule to accept only what goes against nature (...), they end up in a complete divorce from it." Here, the philosopher denounces and condemns unnatural actions, consisting of "moving the land, closing the seas, throwing the rivers into the abyss, suspending the woods" [5], which would not be without damage to nature and to the man who is the author. The consequence is that the latter creates disorder in the natural environment by degrading it. It should be noted that even if it is painful to respect the order of the cosmos, it must be recognized that it is not without interest. Isn't this why, according to the Stoics, in order to live better, it is absolutely necessary to know nature?

\subsection{Universal Sympathy as the "Holistic Dimension of Nature"}

The human being is endowed with reason that is at work in the universe, which allows him to apprehend the functioning of the universe and to live in accordance with it. As such, he has a special status obliging him to respect the cosmic order so that harmony reigns. He discovers through the study of nature that all the elements are united and connected; nothing is isolated and everything is interdependent. A. Bridoux (1966, p. 90) confirms this well when he writes that "everything is linked to everything in space as well as in time; the general cha- 
racter of the universe in which everything depends on everything" [6]. Nature constitutes a "Whole" formed by all its parts that are related to each other. Seneca says, to this effect, that "everything is in everything" and we will speak in Stoic language of universal sympathy:

"The sympathy of the elements of the cosmos shows and imposes that the cosmos is unified, that is to say continuous, a whole without emptiness, where all the parts are necessarily linked. ...] when a finger is cut off, says Sextus, it is the whole body that suffers, an example that must be understood in the definition of a body as a system, in which all parts are interdependent and linked. The world is thus this unified whole, composed however of sufficiently heterogeneous parts to admit notable transformations [...] without nevertheless compromising its unity. Without compromising its unity [7]."

Starting from the notion of sympathy- "sympatheia is a co-affection of the parts, affected by the other parts taken as a whole"-expressing the bond of reciprocal dependence up to the universal scale that exists between the parts of the whole that is the world, one is tempted to affirm that the idea of "the holistic dimension of nature" [8], according to Daniel Desroches (2014, p. 283), so dear to ecologists, would be inspired by the stoicism that indicates that each being or part has an influence on the totality that is nature that must be taken into account before acting. From stoic holism we can retain that the world is continuous and when we touch one element it affects all the others. And by this, it is important to make it known that the harmony and balance of the world depends on the quality of this interaction; which engages the total responsibility of the human being who must know in his soul and conscience that the slightest gesture has consequences on the whole of nature. The most eloquent illustration of universal sympathy comes from Chrysippe when he says that a drop of wine thrown into the sea scatters and mixes with the whole world:

"A cup or even a single drop of wine that falls into the Aegean Sea or the Sea of Crete, will reach the ocean and the Atlantic Sea not by touching them superficially, but by spreading out in all dimensions, in depth, in width, and in length. This is what Chrysippe admits in the first book of "Physical Research": "Nothing prevents a drop of wine from mixing with the sea"; and so that we are not surprised, he says that "thanks to the mixture, the drop will spread to the whole world [9].”

Whatever its magnitude, any action taken has a direct impact on the entire cosmos. The smoke from incense is capable of reaching all parts of the cosmos. Seneca's example, relating to atmospheric phenomena, also illustrates the notion of universal sympathy, and can serve to make man aware of his relationship with nature. The philosopher, who through his reflections appears to be a thinker of all times, identified air with the divine breath in Natural Questions and showed that it is a vital source for all living beings. According to Seneca, this breath plays 
the role of a vehicle that feeds the stars and earthly beings through its connection between heaven and earth:

"Thus, the air is a part of the world, and certainly necessary. It is what binds heaven and earth together, what thus separates the highest regions from the lowest, so that yet it unites them. It separates them, because it interposes itself between them; it unites them because through it each of them is in sympathy with the other; it gives above it all that it receives from the earth, and conversely it transfers the energy of the stars to earthly things [10] (Seneca, 1961, II, IV, 1)."

In commenting on this passage, Valéry Laurand indicated that air must be considered as a true agent of universal sympathy. The description of the function of air, which shows the importance that should be given to it, could lead one to consider the extent of the damage that could result from air pollution, which presents itself as an invigorating agent for the whole world. On the other hand, the Stoic philosopher further showed how all parts of the universe are equivalent and each contributes in its own way to giving meaning to the whole that is the cosmos. After sea water and air, which serve as a vehicle of communication throughout the world, there are the flora, fauna and land, which are also parts of nature and which sympathize both with each other and with the rest of nature. Each one of them plays a specific role and without them the universe would not exist:

"What I call quasi-parts of the world are, for example, animals, trees. For the kind of animals and the trees are part of the universe, since they contribute to the completion of the whole and the universe does not exist without that. But a single animal, a single tree is only a quasi part $[\ldots]$ it is that indeed the universe would not exist more without one than without the other. But the earth is also matter of the universe, because it contains all the substances from which the food that all animals, plants and stars share comes from. It is from it that all individuals draw their strength, and the world from which to satisfy its innumerable needs; it is from it that nourishes, night and day, these so many active, so greedy stars, which need food in proportion to their activity. This is where nature draws as much as its maintenance requires [11]."

We understand more than that any element that constitutes a whole, a whole like the world, is not to be neglected if it has a vocation to exist. But the ecological consequence, which is moreover implied, is that Seneca condemns with the utmost rigor any idea of anthropocentrism, which relates everything to the human species and consecrates its supremacy over everything else. On the contrary, if this one finds itself at the top of the hierarchy of the beings because of its rationality, it is to assume a responsibility, that to take care of the maintenance of the balance and the order having to reign in the universe. In that, the study of nature proves to be necessary because, it has no other objective than to appro- 
priate ethical tools which will make it possible not to break the harmony and the balance with all the natural beings, and, by there all the universe. Stoicism affirms the unity of the world in which everything is intertwined and holds together. It is the internal solidarity of the cosmos. This is what Marcus Aurelius repeats (1953, VII, 9):

"All things are interwined with one another; their sequences are holy, and almost none is alien to the other, for they have been ordered together and contribute to the ordering of the same world. For there is but one world which embraces all, [...] but one substance, one law [...] [12]".

\subsection{From Social to Ecological Oikeiosis}

An awareness is imposed to man from the knowledge he has of nature and which obliges him on the one hand, not to isolate himself and on the other hand, to act in synergy with all other beings and in a way to have less negative impacts on the world. Its happiness depends on it; because it will contribute to its own destruction if it only degrades nature. His weapon is his reason within himself, the guiding part, the use of which will enable him to desire that which cannot disturb his soul, and which would be at the same time that which requires a lesser exploitation of nature. In this sense, the preservation and safeguarding of nature is nothing other than the direct consequence of self-realization, which is synonymous with the tranquility of the soul and happiness. But before tackling this aspect, it would be good to return to the notion of oikeiôsis, a Stoic principle, whose value is no less ecological.

It is the principle of oikeiôsis whose development cannot be exhausted; it served Stoic philosophy as the foundation of anthropology. It is also this principle that allowed Seneca to found his theory of education by indicating that there is both rupture and continuity between instinctive life and rational life from the age of reason, which corresponds to seven years. According to him, he who has not received philosophical education is governed by his primary impulse, instinct. The argument that the Stoics used to question the Epicurean doctrine of happiness, and which seems convincing, comes from the oikeiôsis, when they showed that the appropriation of oneself, that is to say the development and conservation of the being, is not only what is specific to man but inherent to all living beings. By the way, Grimal (1991, p. 369) tells us: "[...] the notion of oikeiôsis which the Romans, since Cicero, at least translate by conciliatio, and which is defined as the tendency [the impulse] possessed by each living being, from the plant to the human being, to ensure the duration of its being" [13]. Consequently, human happiness can only be based on what distinguishes it, namely reason. Apart from plants whose care is provided by nature itself, the self-preservation of animals, including man, is taken care of by themselves. Like all animals, man seeks what is pleasing to him and rejects its opposite. He takes care of himself thanks to the love he has for himself from birth. However, when he grows and procreates, he takes care of his children and they feel a sense of af- 
fection towards him. This bond of attachment and familiarity extends to everything from the nuclear cell to the universal family. Hence the idea of cosmopolitanism when the Stoics speak of the citizen of the world. The notion of the principle of oikeiôsis, as we have seen, already appears at three different levels. Firstly, it characterizes the primary impulse that pushes every living being to act to ensure its survival, which can be described as instinctive oikeiôsis; secondly, with the constitution of reason which makes man's particularity, judgment intervenes so that there is harmony, concord in itself and in conduct, this is rational oikeiôsis. Finally, the feeling of sympathy that binds one to another up to the universal scale is social oikeiôsis. And in an analogous way to this, we can speak of ecological oikeiôsis, which is nothing other than this feeling of familiarity that extends from the human race to all natural beings, the earth and the whole universe. It is in this sense that we are attached to this landscape, this animal, this place or this watercourse. All in all, we discover that this principle plays an eminently important function in man's environment. This idea is found in Carlos Levy (1997, p. 165) when he says that:

"The oikeiosis is in the same relation to oneself and to the world. To continue to live, to realize his nature, the living being must seek certain things and avoid others. Already at the stage of the instinct is perceived the differentiated character of the environment [...] [14]."

And nature is the common feature of all beings because it is present in each of them for having created them. In this sense, everything is called to tend towards the universal. The synthesis of the principle of oikeiôsis seems well done through this fragment of Rodis-Lewis Geneviève (1970, p. 128):

"By his creative intelligence and his work, man arranges his 'habitat', extending his living environment. This 'famous oikeiôsis' of the Stoics, the principle of the animal's natural adaptation, is taken over by reason, which grasps and understands everything in its relationship with the Whole, and thus transforms experience, a succession of individual situations, into universal organization [15]."

\section{Seneca and the Question of the Environment}

Above all, it will be a question of showing that a virtuous life has a positive impact on nature. In addition, a brief presentation will be given on the evidences of Stoic thought on environmental issues.

\subsection{Education in Virtue as the Basis of the Principle of Moderation}

Reason being what defines man, it needs to be well developed, in order to allow us to know the laws and the way nature works. This knowledge aims to make use

of reason, which is absolutely essential to maintain the harmony and balance of the cosmos. And this would only be the fruit of a virtuous soul, which is in har- 
mony with itself. Stoic happiness is synonymous with the tranquility of the soul, which cannot be the accumulation of material goods but only the practice of virtue which is the expression of self-limitation of desires to be satisfied with the little; which does not mean poverty. It emerges that the satisfaction of needs is not condemned, but only excess; for Seneca affirmed that "vice exists as soon as there is excess." In other words, abuse in all things is harmful and virtue is the expression of measure, moderation. Hence the rule of wisdom, which is absolutely salutary:

"Hold therefore this rule of existence, rational and salutary, to grant your body only just what is necessary to be well. ...] Eat only to quench hunger; drink only to quench thirst; your clothes only as a safeguard against the cold; your houses only as a defense against the weather. Is the building made of grass or foreign marble of various shades, it does not matter. Know that man is as well under thatch as under a golden roof. Disdain everything that arranges for ornament and decoration a superfluous art. Consider that nothing is admirable, except a soul, which finds nothing great if it is tall [5] (Seneca, 1993, 8.5)."

Man cannot live without acting on nature, but the problem arises in terms of use. All the interest of the modern reader in stoicism could be situated at this level. To refuse excess is to refuse vice, and this is what brings concord and tranquility of soul, and at the same time participates in the safeguarding of nature. The sage of the Portico, in his concern to maintain the health of the soul by avoiding all that can disturb it, seeks only to satisfy its necessary needs. He confines himself to the essential, avoiding excess, luxury, superfluity, abuse and therefore all waste, in order to devote himself resolutely to what is sufficient. This means that from the outset he is a proponent of moderate consumption, the consequence of which would undoubtedly have a minimal impact on the environment. It is a life of sobriety that could be the subject of an invitation or recommendation to the human race to lessen the effects of pollution and the degradation of nature. But the most important appears to be the educational project elaborated by Seneca, which emphasizes the habitus animi, a virtuous disposition of the soul, which implies a life of simplicity, which naturally translates into ecological behavior, thus a means par excellence to preserve the environment. This could be seen as an incredibly modern solution to the thorny problem of how to reconcile the necessary pursuit of progress with the protection of the natural heritage. If global warming is today a source of fear, according to Seneca, the only way to combat it is to limit desires. And this should be a matter of great concern in order to appeal to the awareness that the unlimited satisfaction of the infinity of desires contrasts dangerously with the scarcity and depletion of natural resources. This could require a reversal of values, and demand consumption in moderation, a habit that one automatically acquires through a virtuous soul, if one is convinced that the total satisfaction of desires would be the cause of environmental problems. 
Apart from these interpretations, which take the place of evidence arising from stoicism regarding ecology, it is time to recognize the relevance of Paolo Fedeli's words, which showed that the environmental problem began in ancient times, and more precisely in Rome, because of the development of economic activities, but which had an extremely minor impact or no impact at all on nature. This means that the observation has been made at least, and Seneca seems to have lived through the situation and borne witness because in his work, certain passages reflect his ecological concerns that have already been investigated by $\mathrm{P}$. Hounsounon-Tolin in his book entitled Rendez-vous chez Sénèque. About ethics.

\subsection{Moral Considerations as an Environmental Issue}

Above all, Seneca rebelled against various forms of pollution and exploitation of nature, especially human activities and techniques used to increase productivity. Thus, he spoke of agriculture, which must necessitate deforestation, the practice of shifting cultivation and then the use of ploughs and fertilizers [5], (1993, 90, $21)$. With regard to hunting, allusion is made to poachers who use various techniques to harvest wildlife [5], $(1993,90,11)$; and with regard to fishing, it is the over-exploitation of bodies of water that is put on the blacklist [11], (1940, p. 189). Questions have been raised about deforestation and the slaughter of animal species [16], (1923, X, 5-6); the exploitation of mining resources has been severely denounced because of their misuse and soil degradation [17], (1972, VII, $10,2 ; 4)$. Finally, what removes any uncertainty about the environmental problem in antiquity and particularly in Rome during the imperial period is the testimony that Seneca gave with regard to air pollution in various forms. It is the pollution of the air by excessive noise that hinders all good meditation for the tranquility of the soul [5], (1993, 56, 1-6). But what the Roman philosopher could not bear was exactly the air pollution by smoke that made him ill and forced him to travel to recover his health:

"You can know what I gained by deciding to leave? No sooner had I left the bad air of Rome and the smell of the smoking stoves which, once in full work, vomit, mixed with dust, all that they have just engulfed with stinking vapors, I immediately noticed a change in my state; you cannot believe how much my vigor increased when I set foot in my vineyard. I let go to the pasture and gave myself to it all I had to drink. I found myself again; this suspicious languor that didn't tell me anything worthwhile disappeared, I started working again with all my soul [5].”

\section{Conclusion}

This study allowed us to show that stoicism could be considered the philosophy that inspired environmentalists. For there is indeed a relationship between them and the Stoics whose principles (unity and order of the world, universal sympathy, principle of oikeiosis and virtue as moderation) develop the idea of the need 
to maintain a harmonious relationship between man and nature. Indeed, the philosophy of the Portico has proclaimed the sufficiency of virtue to lead man to happiness. The health of the soul is what should be of primary concern; it is realized when the soul is free from the passions of desire and fear, which are born when one rebels against the order of nature. When man disassociates himself from nature, he runs to his ruin. Nature is the expression of the principle of cause and effect; this should make men aware of the consequences of their actions on it and oblige him to be in connection with all natural beings. The Stoic happiness which consists in "living in harmony with nature" is realized by virtue, judgment and not by the total satisfaction of desires which, in reality, only engenders fears that make the majority of men unhappy. Taking advantage of nature through the satisfaction of his needs, it is his duty to treat it with respect and to protect it by limiting his desires, to be satisfied with little, that is to say what is enough.

As can be seen, Stoicism is more topical than ever in that it can effectively contribute to the preservation and preservation of nature. But will the contemporary world be able to adopt such a philosophy?

\section{Conflicts of Interest}

The author declares no conflicts of interest regarding the publication of this paper.

\section{References}

[1] Duhot, J.-J. (2003) Epictetus and Stoic Wisdom. Albin Michel, Paris.

[2] Fedeli, P. (2005) Ecologie Antique, Translated by Isabelle Cogitore. Infolio, Paris.

[3] Ferry, L. (2006) Learning to Live. Plon, Paris.

[4] Hounsounon-Tolin, P. (2011) Rendez-vous chez Sénèque. L’Harmattan, Paris.

[5] Seneca (1993) Entretiens. Letters to Lucilius. R. Laffont, Paris.

[6] Bridoux, A. (1966) Le stoïcisme et son influence. Vrin, Paris.

[7] Laurand, V. (2005) La sympathie universelle: Union et separation. Revue de Métaphysique et de Morale, 4, 517-535. https://doi.org/10.3917/rmm.054.0517

[8] Desroches, D. (2014) La Philosophie comme mode de vie. Presses de l’Université de Laval, Québec.

[9] Pseudo-Plutarque (1993) Opinions des philosophes, Translated by Lachenaud G. Les Belles Lettres, Paris.

[10] Seneca (1961) Questions naturelles, tome I, traduit par Paul Oltramare. Les Belles Lettres, Paris.

[11] Seneca (1940) Questions Naturelles, Translated by François and Pierre. Richard. Garnier et Frères, Paris.

[12] Marc, A. (1953) Pensées, Text Established and Translated by A.I. Trannoy. Les Belles Lettres, Paris.

[13] Grimal, P. (1991) Sénèque ou conscience de l'empire. Fayard, Paris.

[14] Levy, C. (1997) Les philosophies hellénistiques. Le livre de Poche, Paris.

[15] Rodis-Lewis, G. (1970) La morale stoïcienn. PUF, Paris. 
[16] Seneca (1923) Consolations à ma mère, Translated by René Waltz. Les Belles Lettres, Paris.

[17] Sneca (1972) Des Bienfaits, tome II, Translated by François Prechac. Les Belles Lettres, Paris. 